\title{
Enhancing Motivation Of Students Completion Of Study Using Rebt Counseling Based On Islam
}

\author{
Eka Damayanti ${ }^{1}$, Muchlisah ${ }^{2}$, Muthmainnah ${ }^{3}$, Subhan Ajrin Sudirman ${ }^{4}$, Muhammad \\ Rusydi Rasyid ${ }^{5}$, Wahyuni Ismail ${ }^{6}$ \\ 1,5,6 Universitas Islam Negeri Alauddin Makassar \\ ${ }^{2}$ Universitas Gadjah Mada Yogyakarta \\ ${ }^{3}$ Universitas Muhammadiyah Enrekang \\ ${ }^{4}$ Universitas Islam Negeri Imam Bonjol Padang \\ Corresponding Email: ekad_psy08@gmail.com
}

\begin{abstract}
Universities are expected to produce quality and timely graduates based on special knowledge in their fields. However, the reality is that several learners are unable to complete their education during this normal period. Many factors and challenges are encountered, such as students' emotional state, social environment, physical health, etc. The purpose of this study is to describe an increase in motivation for study completion after Rational Emotive Behavior Therapy (REBT) counseling for Biology Education students who are on the verge of dropping out. This descriptive quantitative analysis was conducted at the Department of Biology Education, Faculty of Tarbiyah and Teacher Training, Alauddin State Islamic University, Makassar. Purposive criteria were used to select seven study participants who almost dropped out of university. The data collection instruments used were a motivation scale, a motivation screening sheet, an ABCDEF model REBT therapy worksheet, an Islamic-based REBT module, and documentary evidence. The data analysis method used is descriptive statistics, and indeed the findings demonstrate an increase in the average value of motivation for completion of the study before (60.14) and after treatment (63.14). Meanwhile, the screening data showed that each subject experienced an increase in motivation to complete the study at each counseling session. The study participants also recognized the value of the Islamic-based REBT method in increasing motivation to complete their studies
\end{abstract}

Keywords: Islamic-Based REBT Counseling, Motivation, Study Completion

\begin{tabular}{|c|c|c|c|c|}
\hline Submission & Review Process & Revised & Accepted & Published \\
\hline April 24, 2021 & $\begin{array}{c}\text { October 26, 2021 - } \\
\text { December 5, 2021 }\end{array}$ & December 16, 2021 & December 17, 2021 & December 29, 2021 \\
\hline
\end{tabular}

\section{Introduction}

In general, the phase that has been passed necessitates efforts to hone cognitive, to create sufficient comprehension as an accomplishment in each level, especially when studying at university (Rump, Esdar, \& Wild, 2017). Being a learner represents achieving the highest aspects of learning. Responsibility in carrying out duties as a student requires maturity. Students are supposed to be able through each lesson appropriately as a form of foundation in preparing for a bright future. The value of education has been regarded as a means of assisting students in achieving success in life, having careers, and acquiring personal satisfaction (Daehlen, 2017) (Dupere, Leventhal, Dion, Crosnoe, Archamboult, \& Janosz, 2015; Lamb \& Markussen, 2011; Rumberger, 2011). Learning achievement will be attained if learning is effective. Learning could be effective if there's enough motivation to learn, interest in lectures, effort to have something, as well as encouragement. As a result, learning accomplishments can be obtained. The lecture process occasionally encounters obstacles in the different steps, which also have no orientation to the future, resulting in the emergence of a sense of 
laziness within students (Utomo, 2009). Internal student factors and external student environment factors (Frostad, Pijl, \& Mjaavatn (2015); Lack of student academic responsibility, role conflicts in students who are studying while continuing to work, students prioritizing organizational activities over academic assignments, as well as scholarly process saturation (Cabus \& De Witte, 2016; Von Simson, 2015). Various problems experienced by students while attending class should be of concern to various parties, ranging from departments, faculties, and universities to learners' families. This is not unusual for cases of lecture obstruction to result in the threat of losing student status, resulting in the decision to end the study period (drop out).

Dropping out of university is a condition where a person's rights as a student are considered lost. Generally, students who leave the system will waste energy in terms of time, effort, and money. It's accurate for both students and the educational institutions where they are educated (Willging \& Johnson, 2004). To process such a complex suspension of dropouts (Grau-Valldosera \& Minguillon, 2013), institutions will be required to determine the reason why students leaving the system (Tinto, 2006). The phenomenon of dropping out of studies has occurred in various educational universities. As shown in the literature study at Anadolu University Turkey, this paper analyzes the implementation of academic achievement from face-to-face lectures to distance education. Evaluate the variables in these models based on cultural differences and investigate learners' reasons for leaving open and distance learning systems. The findings of this study indicate that there is a correlation between learning motivation and students' perceptions of the reasons for leaving the campus system, which leads to dropout rate (Aydin, Ozturk, Buyukkose, Er, \& Sonmez, 2019).
Numerous different studies have found a link for both learning motivation as well as demographic studies of students taking the Massive Open Online Course in China, the United States, India, Mexico, Canada, Brazil, Taiwan, Egypt, Spain, and Nigeria (MOOC). Those who have a positive attitude toward learning gradually demonstrate satisfying learning outcomes (Zhang, Bonafini, Lockee, Jablokow, \& Hu, 2019). Motivation affects an individual's interest in learning, it is one of the most powerful internal factors in encouraging students to complete their studies (Slameto, 2006). According to Ainurrahman (Yuliani, 2013), motivation in learning activities becomes a strength that enables individuals to function their potential within themselves as well as every one's ability out beyond themselves to achieve learning goals.

Dropouts are also found at UIN Alauddin Makassar, particularly in the Biology Education Study Program. The rules for dropping out of UIN Alauddin Makassar study are as follows: (1) if the student does not register or expect to be paid university fees on time; (2) if the student has spent the effective study period (14 semesters) but have not been able to finish your studies by August 31, the current academic year; and (3) if the student has spent a minimum of 2 semesters of study but have not been able to complete GPA 2.00 (Handbook UIN Alauddin Makassar Students, 2013). Although academic rules clearly explain dropping out of university, the fact remains that many learners, particularly from the Biology Education class of 2011, appear to be hampered in completing their degree. The indicator could be seen in the fact that it appeared once during the thesis title submission but never again for consultation with the supervisor. Some never appear at all for the approval of research titles, even after the deadline has passed.

Yatmono and Zamtinah in Hariyadi, Anto, \& Sari (2017) described that late final 
project is due to the unpreparedness of students to complete the thesis research title, the process of implementing guidance is not intensive (due to ineffective supervisor and students communication), the unavailability of adequate media and places to do the thesis, as well as the ineffectiveness of sanctions for students who do not meet the target time for completing the final project. Based on data from the 2016 Higher Education Database (PDPT), there were 25 students in the Department of Biology's class of 2010 who had a GPA above 2.0, with some even reaching 3.0. Not to mention that there are 10 students with a GPA below 2.0. That being said, according to information obtained from the Biology Education Education Department staff (Tuesday, 28 March 2017 at 08.00 in the Biology Education Department Room), the number of students in the Biology Education Department's 2011 class can still be attempted to graduate this year is seven. This could not be separated from the learners' own motivation to pursue their education. Students must always be motivated in needed to finalize their studies. Motivation is someone's encouragement to do anything to achieve a goal. Psychosocial factors such as motivation offer learning success to students, good learning outcomes are the strongest predictors of subsequent graduation (Casillas, Robbins, Allen, Kuo, Hanson, \& Schmeiser, 2012). A person will be highly motivated if he realizes and comprehends the goals he intends to achieve in the future (Dillahunt, Wang, \& Teasley, 2014; Hew \& Cheung, 2014; Kizilcec \& Schneider, 2015). It can be concluded that the motivation for completing the study is the encouragement of students to conduct thesis research as soon as possible so that they might easily advance to the thesis and judicial examination stages and obtain a bachelor's degree (S1). according to Susanti's research (2015) which states that the cause of the delay in completing the thesis is that most students are lazy to complete the final project and lack motivation. Motivation in completing academic studies can be defined as what a student does to accomplish their studies by the deadline set by the university. Learners who are motivated to complete their studies have a positive impact on the productivity of their project, are resistant to challenges, are interested in solving various problems, prefer to work independently, and do not get easily bored while preparing a research paper from each phase. Self-encouragement could create motivation to finish this report by recognizing one's duties and responsibilities as a student. In regards to encouragement from within, external motivation in the form of support from parents, peer groups, and supervisors can help students complete their final assignments and arrive at college on time. In such cases, the Department Head must deal with the faculty members.

Efforts were made in the Biology Education Department to process the completion of student studies, including calling one by one student who has been identified as experiencing delays in the process of achieving the target period of study. Nevertheless, engaging with all these students necessitates preferential treatment. Based on the interview with the Head of the Department of Biology Education on Tuesday, March 28, 2017, at 09.00 in the Education Room of the Department of Biology, it conclude that the Head of the Department of Biology took the initiative to enable decision-making for problems of learning motivation for students of the Department of Biology, one of which required an interpersonal approach. Such as a psychological approach in the form of counseling from a psychologist. Handayani's research (2017) illustrates that the highest learning motivation in students is dominated by the need for goal orientation, which is significant because it is the primary basis for students to foster an intrinsic drive to complete 
their studies. The appropriate counseling model used according to Ellis in Jones (2011) is in the form of Rational Emotive Behavior Therapy (REBT) counseling is to improve negative beliefs into rational and realistic beliefs so that students can find their inner motivation. Intrinsic motivation refers to students' belief in how they can finish their studies on their terms. Then according to Sismadi's (2016) research, self-esteem is necessary for the educational process because it affects educational success. Self-esteem was raised in this study through Islamic-based REBT counseling. Furthermore, Amaliyah (2015) conducted research that emphasized the effect of REBT training on reducing student anxiety when writing theses. Sartika (2017), on the other hand, used the concept of gratitudebased REBT counseling to help adolescents improve their self-concept. This is intended so that adolescents can reach their aims mostly with self-assurance, optimism, and enthusiasm. The educational environment can even have a positive influence on students' learning outcomes. Certainly, it promotes a great deal of achievement in the process of completing education in the student environment. The emphasis of Islamic-based REBT counseling is the researchers' assumption throughout this study, which is expected to contribute to motivating the students to complete their work. Researchers attempted to incorporate Islamic aspects into their frameworks in this research paper by altering them so that Islamic elements predominated. Researchers will use the Spiritual Emotional Freedom Technique (SEFT) technique as one of their strategies. According to Nurlatifah (2016), SEFT is a breakthrough in counseling techniques. The technical stages make use of the physical, psychological, and spiritual aspects of humans in a balanced manner. These three factors are used to assist the counselee in resolving his or her problems. SEFT's spiritual component is consistent with Islamic Guidance and Counseling, which includes spiritual and religious elements in all of its scientific viewpoints.

Islamic-based REBT counseling is designed to help students understand their existence as a creature of Allah SWT, who essentially lives according to the teachings of Islam (Musnamar in Khotijah \& Rahman, 2016). It is hoped that by using a religious approach, students will be able to evaluate themselves and enhance their belief that placing forth the maximum effortand processes possible, provides useful results will be obtained. The whole research is meant to prove assumptions about the effect of Islamic-based REBT counseling on increasing study completion motivation for Biology Education students who are threatened with dropping out of a study at UIN Alauddin Makassar, referring to several reasons for the need for dealing with students who are hampered by their study process through a religion-based counseling approach. Relying on the context of the current problems, the main issue for this research iswill be the description of the motivation for study completion in Biology Education students who are threatened with dropping out of their studies following the application of Islamicbased Rational Emotive Behavior Therapy (REBT) counseling.

\section{Research Methods}

Seperti halnya pada penelitian kuantitatif, metode penelitian pada penelitian kualitatif mengacu pada pendekatan kualitatif yang digunakan oleh peneliti (case study, phenomenological theory, grounded theory, narrative inquiry, content alalysis, critical inquity, ethnography, dan sebagainya).

Dalam rancangan penelitan, peneliti menuliskan langkah-langkah/prosedur dalam melakukan penelitian kualitatif yang juga mencantumkan metode sampling dan pertimbangannya. Populasi dan sampel 
berisikan tentang jumlah partisipan yang terlibat dalam penelitian dengan disertai dengan karkateristik/aspek demografis. Pada metode pengumpulan data, peneliti menguraikan secara detail pendekatan dalam mengumpulkan data (e.g., wawancara, observasi, dan sebagainya) dengan penjabaran jenis teknik yang digunakan (e.g., wawancara terstuktur, observasi partisipan, dan sebagainya). Terakhir, untuk metode analisis data, peneliti mencantumkan pendekatan dalam menganalisis data yang diperoleh. Pada penelitian kualitatif, beberapa jenis pendekatan analisis data yang diperoleh sebagaimana interpretative phenomenological analysis, thematic coding, dan sebagainya.

Untuk penelitian kuliatatif yang menggunakan pendekatan literature review dan systematic review, peneliti perlu menyebutkan prosedur sistematika penelusuran data, seperti menyebutkanonlinedatabase yang digunakan untuk memeroleh data (e.g., ProQuest, Sage Journal, Elsevier, dan lain sebahainya) dan kata kunci yang digunakan untuk menelusuri litaretur.Selain itu, peneliti juga perlu menyebutkan proses dari data extraction, baik berupa uraian maupun berupa flow chart. Proses data extraction dalam bentuk flow chart adalah sebagaimana contoh di bawah ini:

This study is descriptive quantitative research conducted in the Department of Biology Education, Faculty of Tarbiyah and Teacher Training, Alauddin State Islamic UniversityMakassar, South Sulawesi. Biology Education was chosen because it had the highest number of dropouts among all study programs at the Tarbiyah and Teacher Training Faculty.

The study population consisted of all Biology education students who were on the verge of dropping out. The selected sample was 7 students who met the following criteria: (1) they were still registered as Biology Education students; (2) they had aGPA above
2.0 ; (3) they had been studying for 11 semesters (more than 5 years); and (4) they expressed a willingness to be a research sample. The instruments for data collection included a project report, a motivation screening sheet, an ABCDEF model REBT therapy worksheet, an Islamic-based REBT module, and documentation.

The REBT module was created using the ABC-DEF and $G$ concepts (Namora in Hartati and Rahman, 2017):

a. An antecedent Event (A) is an event that leads to a personal experience. Events that occur, with various processes involved, and that ignore elements of good or bad experiences. Although the counselee is suffering as a result of recalling the memory of the experience. In therapy, the counselee is encouraged to believe that the incident is true in the hope that it will create a situation in which the counselee will be able to feel a mental problem by giving meaning to the situation of the incident has occurred.

b. Belief (B) is an individual's perceptions, values, points of view, and interpretations of an event. People have two kinds of belief systems: rational and irrational beliefs. Rational belief is defined as a rational way of thinking that is wise and productive. Meanwhile, irrational belief refers to the ability to believe in individuals who have the wrong system, which is dominated by emotional feelings and produces unproductive thoughts.

c. Emotional Consequence $(\mathbf{C})$ is a result of an individual emotional reaction that resultsin a pleasant feeling or an emotional barrier when associated with experience (A). The incident (A) does not directly cause this emotional feeling, but rather the belief created by the individual through belief (B), whether rational or irrational. 
d. Disputing (D) is the application of scientific principles against self-defeating thinkingand unprovable irrational values.

e. Effect (E) is the final outcome of the ABCD process, manifested as cognitive and emotional behavior. When the ABCD process is carried out in a rational manner, it results in positive behavior. If, on the other hand, the thought process is irrational, the outcome will be negative behavior.

f. New Feeling (F) is a goal in this counseling that means there is a new feeling in interpreting the process of each event. It is hoped that by discovering new beliefs, people will be better able to distinguish for both rational and irrational thoughts, allowing them to better position themselves to deal with difficult situations by encouraging rational thinking.

g. Goal (G) is presented at the beginning before the ABCDEF process is carried out so that the individual knows the purpose of the counseling session during this phase.

Islamic-based REBT counseling is technically carried out in this study in the form of direct communication with clients in a group setting. This was done because it was assumed that the students who served as study samples all had the same problem. The REBT model is implemented by using the ABCDEFG technique and including Islamic content in the affirmation sentence. Technically, the ABCDEFG model is combined with the Spiritual Emotional Freedom Technique (SEFT).

In specifics, the distribution of Islamic content with the awareness that humans are born with the potential for hearing, sight, and reason to know which ones are good and which are bad and have the power to choose the greatest for themselves. The combination of Spiritual Emotional Freedom Technique (SEFT) is intended to assist the subject in realizing his spiritual potential in order to overcome his emotional issues.

The motivation scale for the completion of the study with the Likert scale model with five answer choices (Strongly Agree, Agree, Disagree, and Strongly Disagree) the researcher compiles into 20 favorable (F) and unfavorable (UF) items based on the motivational indicators of Bakar (2014) namely diligently working on theses, enduring difficulties, showing interest in various problems, preferring to work independently, and not being bored in doing theses. The whole scale hasacquired validator credibility and has been tested on 50 Tarbiyah and Teacher Training Faculty learners who are currently working on their thesis. As a result, there are 17 valid items and 3 items with validity values ranging from 0.284 to 0.709 , as well as a Cronbach's Alpha reliability value of 0.723 and a Cronbach's Alpha Based on Standardized Items value of 0.839 (> 0.6), indicating that the items are reliable and acceptable. The descriptive statistics data analysis technique with the help of the excel program was used to measure the average score of study completion motivation as well during the Islamic-based Rational Emotive Behavior Therapy (REBT) counseling treatment.

\section{Results and Discussion}

The descriptive analysis of the research completion motivation scale results show a description of the motivation data for study completion before the minimum value of treatment is 47 and the maximum value is 70 , with a mean of 60.14 . A maximum of 69 was recorded, with a mean of 63.14. 
Table 1.

Descriptive Statistic

\begin{tabular}{lrrrrr}
\hline & N & $\begin{array}{r}\text { Mini } \\
\text { mum }\end{array}$ & $\begin{array}{c}\text { Maxi } \\
\text { mum }\end{array}$ & Mean & $\begin{array}{c}\text { Std. } \\
\text { Deviation }\end{array}$ \\
\hline BEFORE & 7 & 47 & 70 & 60.14 & 8.513 \\
& & & & & \\
AFTER & 7 & 57 & 69 & 63.14 & 3.761 \\
Valid N & 7 & & & & \\
(listwise) & & & & & \\
\hline
\end{tabular}

Furthermore, it was discovered that the seven research subjects experienced an increase in motivation for study completion after the Islamic-based REBT treatment was carried out, based on the graph of the motivation screening data for the completion of the study of eachsession (for 5 sessions it had been held).

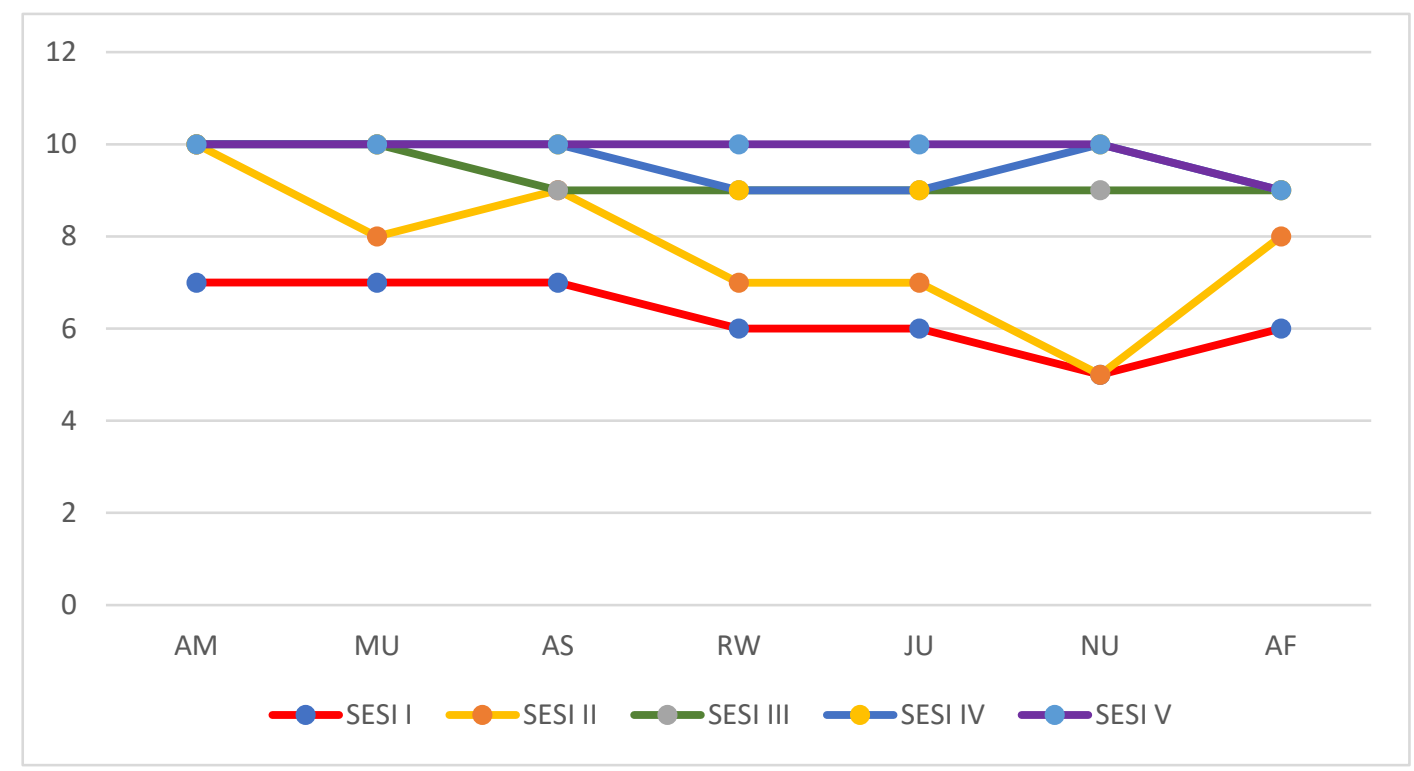

Figure 1. Study Competition Motivation Screening Data.

Figure 1 shows that the AM sample's motivation to complete the study was only at level 7 in session I, but it increased and remained at level 10 in meeting II and the following session. Similarly, in session, the MU sample's motivation level for completing the study was at level 10 . Level 7 was increased to 8 in session II, and level 10 in the following session. The US sample also experienced an increase in motivation to complete the study, beginning with level 7 in session I, then stages 9 in sessions II and II, and 10 in sessions IV and V. RW Sample and JU also reported a rise in motivation; in session I, RW and JU had a level of motivation for completion of the study that was initially at the session I at level 6, then at the session I at level 7 , and doubled again after sessions III and IV at level 9, then at level 10 in session $\mathrm{V}$. The NU sample as well boosted, originally only to level 5 in sessions I and II, but dramatically to level 9 in session III and 10 in session V. Finally, the AF sample was initially only level 6 in session I, but it continued to increase to 8 in session II and 9 in sessions III, IV, and V. In general, the study completion motivation screening process was effective. This indicates that there was a positive change during the process of receiving treatment in the form of REBT counseling, as evidenced by increased motivation for study completion in all participants.

Referring to the theory, motivation itself is a driving force for action or action. According to Nancy Stevenson in Kartadinata (2001), motivation is all verbal, physical, or psychological things that make someone do something in response. Thus, the motivation for completing the study is an encouragement 
that is possessed by students so that it encourages study completion behavior such as being diligent in facing the supervisor to consult their thesis sothat they can be judged before the deadline of the study period. This has been attempted during the treatment process in the counseling session. Participants are given reinforcement to help them realize their current situation, instill confidence, introduce the consequences of feelings and emotions caused by life events, assist in the implementation of a planned lifestyle, and generate positive thoughts. Naturally, the therapeutic patterns in this research were based on the ABC-DEF model in REBT therapy (Namora in Hartati \& Rahman, 2017). Weiner in Nursalam and Efendi (2008) further defines motivation as an internal drive that awakens individuals to act, achieves certain goals, and keeps individuals focused on an effort/activity in achieving their goals. Uno in Nursalam and Efendi (2008) also defines motivation as an internal and external drive in an individual as measured by (a) the desire and interest in carrying out activities; (b) Encouragement and need to carry out activities; (c) a description of hopes and dreams; (d) create self-respect and respect; (e) creates a favorable environment; (f) manifest in interesting activities. Motivation is something that can lead individuals to act towards their goals.

During the counseling session, participants showed a willingness to implementation to complete the thesis preparation process. In line with the results obtained, research from Hartato (2016) has found that: (1) Motivation to immediately graduate from college has a positive effect on the completion of the thesis final project, in addition to that (2) Student strategies to strive to be able to complete their final assignments in the form of mastering skills Techniques for writing scientific papers are also needed, (3) Facilitating learning resources is also supportive, (4) Quality in thesis guidance, and
(5) The influence of the friendly environment contributes to encouraging students to increase their learning motivation. In this study, participants demonstrated progressive efforts made, such as forming groups with friends who shared a similar interest in the research and had completed their thesis. This is solved to participate more actively in the completion, and they also learn techniques for completing their lectures easily. In addition, the participants created a behavioral checklist that included concrete steps that had not been, while, and had been finalized. Hakim (2000) Hakim (2000) gave several points in trying to increase student motivation to complete the study: (1) Students are expected to understand and find the benefits of each stage in the process of preparing the final project; (2) Choosing a fun/comfortable way in pursuing the final assignment preparation process; and (3) Trying various alternative solutions, such as trying to find references, maintaining good relations with the supervisor, and limiting relationships that can bury the urge to stay focused on completing the final project. In this study, especially at the last meeting of the counseling process, participants admitted that they were more often and more focused when they were in the library than at their boarding house.

They try to get out of their comfort zone (disputing) to get together with their friends and chat at the boarding house. It is important to note that motivation is developed within oneself and does not rely on others. According to Bakar (2014), motivation in the educationprocess can be seen in their learning behavior, has a high motivation to learn to be diligent in doing assignments, is resistant to difficulties, displays interest in various concerns prefers to work independently, and is not bored in doing tasks. On the authority of Kartadinata (2011), there are several ways to motivate someone (Kartadinata, 2001), namely: (1) Motivating by force namely 
motivating by using the threat of punishment or violence. So those who are motivated could do what needs to be addressed; (2) motivating by enticement, notably motivating with persuasion or giving gifts to do something as expected, which provides motivation; and (3) motivating by identification, particularly regarding motivating by instilling awareness so that people do something because of a desire to achieve everything which arises from within themselves. In addition, to study completion motivation scale data and study completion motivation screening data, researchers also collected qualitative data regarding the cognitive and emotional processes of the sample in carrying out the Islamic-based REBT counseling process using the ABCDEFG technique.

The results describe the different dynamics between samples. However, basically, the pointis the same that after REBT Islamic-based counseling, they realize that there are irrational beliefs that they have to discuss to find back motivation in the completion of the study. Theresearch subjects felt the importance of the Islamic-based REBT method in increasingmotivation in completing their studies. Individual belief in solving problems requires emotional strength, which serves as the driving force for individuals to find solutions in solving them. Based on the researcher's exploration of the subjects' beliefs, emotions, and problem-solving abilities, it was discovered that seven subjects were able to instill confidence in themselves to complete their thesis. According to Ellis (2002), Rational Emotive Behavior Therapy (REBT) is based on the idea that people have beliefs, emotions, and the ability to overcome adversity. Baharuddin (2009) explains that one of the supporters of the formation of motivation is that the individual needs knowledge in the use of free time, so that lecture activities such as looking for references, doing assignments, to discussing with friends are suggestions that increase adolescent interest in lecture activities. However, the subjects AM, MU, $\mathrm{RW}, \mathrm{JU}, \mathrm{NU}$, and $\mathrm{AF}$ showed problems in facilitating them to prioritize time in taking advantage of opportunities in the lecture process. Family problems, the condition of the body in a state of illness, and doing side work activities are sources of problems that require time to resolve. Baharuddin (2009) explains that one of the supporters of motivation establishment is that the individual requires knowledge in the use of free time, so lecture activities such as looking for references, doing assignments, and discussing with friends are suggestions that significantly raise adolescent interest in classroom activities. However, the subjects AM, MU, RW, JU, NU, and AF had difficulty prioritizing time in order to take advantage of opportunities in the lecture process. Family problems, the condition of the body in a state of illness, and doing side work activities are sources of problems that require time to resolve. This is what underlies the obstacles in increasing lecture motivation and completion of theses on research topics.

Rational Emotive Behavior Therapy (REBT) counseling departs from the understanding that individuals have beliefs, emotions, and the ability to overcome adversities. Individual belief in solving problems requires emotional strength which is the driving force so that individuals can find solutions in solving them. The goal in REBT counseling is to hone the individual's ability to feel every life process that is lived, its consequences, and to generate positive emotions as a driving force that encourages people to solve problems (Ellis, 2002). The formula in Rational Emotive Behavior Therapy (REBT) counseling is debatable; in theory, it's also described in the ABCDEF sequence, where A (activating event) is described as a problem, B (belief) is a belief system, and $\mathrm{C}$ (consequences) is a consequence received that is not due to the 
problem but due to the impact of belief in the problem itself. The consequences are positive if indeed the belief in the problem is rational. If the consequences are negative, what can be solved is to train individuals to be able to D (dispute) or against these irrational beliefs. Until it finally gives rise to $\mathrm{E}$ (effective) or effect and $\mathrm{F}$ (new feeling) or new beliefs that are more rational, and in the end, the individual is automatically able to use the skills he has to overcome his problems, including discovering the source of his motivation (Dahlan, 2009).

The counseling process has reached its main goal, and that was to establish a disputing process for negative motivation and irrational beliefs that obstruct the formation of a process for building positive motivation. Dahlan (2009) emphasizes that Islamic-based REBT Counseling is in the form of using a disputing formula that aims to build confidence in individuals through a faith approach. The initial process used in this study was able to instill confidence in the research subject, allowing it to progress to self-development, which served as the foundation for developing positive motivation for study completion. By incorporating or incorporating Islamic elements into the REBT counseling technique, it is hoped that it willnot only assist students so that they have psychological, physical, moral, and intellectual toughness, but also the spirituality of the student's school can learn from Allah SWT.

REBT based on Islam was created to assist in re-empowering the potential (aql, qalb, and nafs, and spirit) contained in individuals who become human nature by reactivating faith and piety so that they can return to function and develop as they should. First, Aql (reason/cognition) is always associated with ethics and morals. This section implies that by engaging in rational thinking, individuals will become aware of the consequences of their actions. As a result, emotional control has been able to predict what will happen (Abdullah in Hartati \& Rahman, 2017). Practice (al-'aqil) are people who can hold and bind their desires. Aql can transport humans to the essence of humanity (haqiqah insaniyyah) (Al-Ashfahani, 1972). Al-Ghazali, like philosophers, radically rejected the existence of aql freedom, despite adhering to formal logic in the development of aql. In psychology, aql is defined as the ability to think, connect, and judge or consider things in life. Alternatively, related to logic-based problem-solving strategies (Zohar \& Marshall, 2000). Second, according to Jalaluddin Rumi, Qalb has a tremendous capacity for thought (Syukur in Hartati \& Rahman, 2017). Based on the hadith narrated by Imam Bukhari \& Muslim: "Remember that there is a piece of meat in the body." If it is good, the body is completely good; if it is bad, the body is completely bad. Keep in mind that the piece of meat is a heart." Qalbu (al-qalb) is one of the nafsani powers. This heart serves as a guide, controller, and regulator of all human behavior. Experts differ in their interpretations of the meaning. Some believe it is organic material (al-adhuw al-madi), while some others call it a cognition system (jihaz indraki ma'rifi) that is emotionally empowered (al-syu'ur) (AlSyinqithi, 1993). In contemporary psychology, the term qalbu is commonly used to represent al-syu'ur (emotion), which is a recognized or realized feeling. Al-Ghazali (1991) has seen the heart in two ways: the physical heart and the spiritual heart, which is related to the physical heart and seems to be subtle (lathif), rabbani, and spiritual. The physical Qalbu is the heart that is the center of the human body. Even though the heart is physical, it's critical to human psychological wellbeing. When a person's mental state is normal, the heart will beat or beat regularly; however, when the psychological state becomes delighted or too depressed, the pulse frequency will be faster or even slower than the normality limit. As shown by this standpoint, the spiritual heart is the 
essence of the nafsani. Third, Nafs is a subtle feeling, which is an element of the human soul and its substance but depends greatly on spiritual conditions (Auliya in Hartati \& Rahman, 2017). The Nafs tend to impose desires as an attempt at self-gratification. While the nafs works to satisfy themselves, Aql behaves like a controller, limiting the nafs' actions to those that should be directed toward positive satisfaction and avoiding negative gratification. In theory, each of these opposing dimensions requires the other. A body without a spirit is a non-living substance, whereas a spirit without a body cannot be realized. The synergy between these two opposing dimensions is allowed for it to become nafs. Each of the body functions and spirit's desires in humans can be satisfied by the nafs.

Fourth, Ruh is a kind of element found in the human that aids qalb role and it is the basis of the heart. The human body is controlled by aql and nafs, which are both in qalb and come alive through the power of Allah SWT. This should be reflected in the human ability to think rationally and the recognition that humans are always servants of Allah SWT as well as leaders on Earth. Humans should be able to follow His teachings with this awareness (Hartati \& Rahman, 2017). In line with Al-Anbari (Al-Ashfahani, 1972), ruh refers to the male form (muzakkar), whereas nafs alludes to the female form (mu'annas). That is the linguistic tradition that Arabs follow. The nafs serves as a bridge between the rational soul and the physical body. The nafs component is linked to the body, while the spirit is not (Al-Kasyani, 1984). As reported by Ibn Abbas (Al-Kufi, 1992), humans have nafs and a spirit. Because the nafs contains aql, the human nafs can suppose and distinguish between right and wrong. The human spirit, on the other hand, can live because it is life. Vertical rays are what Burckhardt (1984) applies to as the true essence. This indicates that God's rays are directly transmitted to humans. Meanwhile, the nafs is a horizontal light, reflecting that God's rays have merged with the human body and generated behavior patterns.

The primary goal of REBT counseling is to establish a rational personality by changing irrational thinking to rational thinking. In this case, counselors believe that human beings will experience emotional disturbances as a result of irrational thoughts in dealing with life. Throughout this treatment plan, living realistically is a baseline. People should be capable of controlling all thoughts that arise from unrealistic beliefs. The capital is in developing a more self-respecting, adaptable attitude, learning to always think scientifically, and developing self-acceptance (Natawidjaya, 2009). By utilizing the concept of individual self-existence through awareness of the nature of human creation, the religious approach is frequently viewed as an effective part in constructing a healthier true identity. Achieving the value of life and enjoying life will be a good ending if the REBT counseling concept can be effectivelyapplied. Having selfinterest, social involvement, being able to direct oneself, being tolerant, flexible, social acceptance, accepting uncertainty, selfacceptance, being able to take risks, having realistic expectations are some of the goals deemed necessary in gaining REBT, have tolerance in a state of high frustration, as well as construct personal responsibility (Komalasari, Eka, \& Karsih, 2016).

The study's findings imply that people can overcome problems by confronting their irrational beliefs. An Islamic approach is required so that humans can recognize the potential of their intellect and be grateful for the life they have. As a result, it is necessary to assist others, such as counselors, or to remind one another to avoid emotional problems caused by irrational beliefs.

\section{Conclusion}


The researcher concluded that since using the Islamic-based REBT treatment, the average motivation to complete the study has increased. It's indicated by the results of the descriptive analysis, which is supported by the results of the screening chart, which reveals that the motivation to complete the study has increased over the five sessions.

Therefore, it is recommended for more in-depth research with a large number of subjects so that data analysis can be carried out using t-test inferential statistics.

\section{References}

Al-Ashfahani, A.-R. (1972). Mu'jam Mufradat Alfaz al-Qur'an. Beirut: Dar al-Fikr.

Al-Ghazali, A. H. M. (1991). Ihya' Ulum alDin. Beirut: Dar al-Fikr.

Al-Kasyani, A. al-R. (1984). Mu'jam alIsthilahat al Shufiyyah. Cairo: Dar alMa'arif.

Al-Kufi, A. al-B. A. ibn M. al-H. (1992). AlKulliyah; Mu'jam fi al-Musthalah wa al-Furuq al-Lughawiyah. Beirut: Muassasah al-Risalah.

Al-Syinqithi, M. S. (1993). Al-Qalb fi alQur'an wa Atsaruha fi Suluk al-Insan. Riyadh: Dal Alam al-Kutub.

Amaliyah, K. A. (2015). Efektivitas rational emotive behavioral training terhadap penurunan kecemasan menyusun skripsi mahasiswa. Jurnal Intervensi Psikologi, 7(2), 143-157. https://doi.org/10.20885/intervensipsik ologi.vol7.iss2.art2

Aydin, S., Ozturk, A., Buyukkose, G. T., Er, F., \& Sonmez, H. (2019). An investigation of drop-out in open and distance education. Educational Sciences: Theory and Practice, 19(2), 40-57. Retrieved from https://eric.ed.gov/?id=EJ1215178

Baharuddin. (2009). Pendidikan dan Psikologi Perkembangan. Ar-Ruzz Media.

Bakar, R. (2014). The Effect Of learning motivation on student's productive competencies in vocational high school, West Sumatra. International Journal of Asian Social Science, 4(6), 722-732. Retrieved from http://www.aessweb.com/pdffiles/ijass-2014-4(6)-722-732.pdf

Cabus, S. J., \& De Witte, K. (2016). Why do students leave education early? Theory and evidence on high school dropout rates. Journal of Forecasting, 35, 690702. https://doi.org/10.1002/for.2394

Casillas, A., Robbins, S., Allen, J., Kuo, Y., Hanson, M., \& Schmeiser, C. (2012). Predicting early academic failure in high school from prior academic achievement, psychosocial characteristics, and behavior. Journal of Educational Psychology, 104(2), 407-420.

Daehlen, M. (2017). Completion in vocational and academic upper secondary school: The importance of school motivation, self-efficacy, and individual characteristics. European Journal of Education, 52(3), 336-347. https://doi.org/10.1111/ejed.12223

Dahlan, A. C. (2009). Bimbingan dan Konseling Islam; Sejarah, Konsep, dan Pendekatannya. Yogyakarta: Pura Pustaka.

Dillahunt, T., Wang, B., \& Teasley, S. (2014). Democratizing higher education: Exploring MOOC use among those who cannot afford a formal education. The International Review of Research in Open and Distributed Learning, 15(5). https://doi.org/dx.doi.org/10.19173/irr odl.v15i5.1841

Dupere, V., Leventhal, T., Dion, E., Crosnoe, R., Archamboult, I., \& Janosz, M. (2015). Stressors and turning points in high school and dropout: A stress process, life course framework. Review 
of Educational Research, 81, 591-629.

Ellis, A. (2002). Overcoming Resistance: A Rational Emotive Behavior Therapy Integrated Approach 2nd Ed. New York: Springer Publishing Company, Inc.

Frostad, P., Pijl, S. J., \& Mjaavatn, P. E. (2015). Losing all interest in school: Social participation as a predictor of the intention to leave upper secndary school early. Scandinavian Journal of Educational Research, 51, 110-122. https://doi.org/10.1080/00313831.201 4.904420

Grau-Valldosera, J., \& Minguillon, J. (2013). When procrastination leads to dropping out: Analysing students at risk. ELC Research Paper Series, 6, 63-74. Retrieved from https://www.uoc.edu/ojs/index.php/elc rps/article/view/1872

Hakim, T. (2000). Belajar Secara Efektif: Panduan Menemukan Teknik Belajar, Memilih Jurusan, dan Menentukan Cita-cita. Jakarta: Puspa Swara.

Handayani, D. R. (2017). Analisis motivasi intrinsik dan ekstrinsik mahasiswa calon guru fisika. Jurnal Kependidikan, 1(2), 320-333. Retrieved from https://journal.uny.ac.id/index.php/jk/a rticle/download/8449/pdf

Hariyadi, S., Anto, A. H. F., \& Sari, W. A. (2017). Identifikasi faktor-faktor yang mempengaruhi penyelesaian skripsi pada mahasiswa S1 psikologi di Kota Semarang. Jurnal Penelitian Pendidikan, 34(2), 155-160. https://doi.org/10.15294/jpp.v34i2.117 52

Hartati, S., \& Rahman, I. K. (2017). Konsep pendekatan rational emotive behavior therapy (REBT) berbasis islam untuk membangun perilaku etis siswa. Jurnal Genta Mulia, VIII(2), 13-26. Retrieved from

https://ejournal.stkipbbm.ac.id/index.p $\mathrm{hp} / \mathrm{gm} /$ article/view/115

Hew, K. F., \& Cheung, W. S. (2014). Students' and instructors' use of massive open online courses (MOOCs): Motivations and challenges. Educational Research Review, 12, 45-58. https://doi.org/10.1016/j.edurev.2014. 05.001

Jones, R. N. (2011). Teori dan Praktik Konseling dan Terapi. Yogyakarta: Pustaka Pelajar.

Kartadinata, S. (2001). Kemandirian Belajar dan Orientasi Nilai Mahasiswa. Bandung: PPS.

Khotijah, L. N., \& Rahman, I. K. (2016). Konsep Bimbingan Konseling Impact Berbasis Islam Untuk Meningkatkan Regulasi Diri Dalam Pemanfaatan Gadget. Jurnal Hisbah, 13(2), 1-13. https://doi.org/10.14421/hisbah.2016.1 32-01

Kizilcec, R. F., \& Schneider, E. (2015). Motivation as a lens to understand online learners: Toward data-driven design with the OLEI scale. ACM Transactions on Computer-Human Interaction (TOCHI), 22(2). https://doi.org/dx.doi.org./10.1145/269 9735

Komalasari, G., Eka, W., \& Karsih. (2016). Teori dan Teknik Konseling. Jakarta: Indeks.

Lamb, S., \& Markussen, E. (2011). School dropout and completion: An international perspective. In In $S$. Lamb, E. Markussen, R. Teese, N. Sandberg, \& J. Polesel (Eds.), School dropout and completion. International comparative studies in theory and policy. Dordrecht: Springer.

Natawidjaya, R. (2009). Konseling Kelompok Dasar \& Pendekatan. Bandung: Rizqi Press. 
Nurlatifah, A. I. (2016). Spiritual emotional freedom technique (SEFT) sebagai terapi dalam konseling. Jurnal Madaniyah, 2(XI), 317-327. Retrieved from

https://journal.stitpemalang.ac.id/inde x.php/madaniyah/article/download/98/ $81 /$

Nursalam, \& Efendi, F. (2008). Pendidikan Dalam Keperawatan. Jakarta: Salemba Medika.

Rumberger, R. W. (2011). Dropping out. Why students drop out of high school and what can be done about it. Cambridge, MA: Harvard University Press.

Rump, M., Esdar, W., \& Wild, E. (2017). Individual Differences in the Effects of Academic Motivation on Higher Education Students' Intention to Drop Out. European Journal of Higher Education, 7(4), 341-355. https://eric.ed.gov/?id=EJ1161834

Sartika, E. (2017). Konseling Rasional Emotive Behavior Therapy (REBT) Berbasis Rasa Syukur Untuk Meningkatkan Konsep Diri Remaja (Skripsi). Yogyakarta: Universitas Islam Negeri (UIN) Sunan Kalijaga.

Sismadi. (2016). Konseling Rational Emotive Behavior Therapy (REBT) Berbasis Islam pada Siswa yang Mengalami Krisis Self Esteem (Tesis). Yogyakarta: Universitas Islam Negeri (UIN) Sunan Kalijaga.

Slameto. (2006). Belajar dan Faktor-faktor yang Mempengaruhinya. Jakarta: PT. Raja Grafindo Persada.

Susanti, R. (2015). Efektifitas konseling realitas untuk peningkatan regulasi diri mahasiswa dalam menyelesaikan skripsi. Jurnal Psikologi Fakultas Psikologi UIN Sultan Syarif Kasim Riau, 11(2), 88-93. https://doi.org/dx.doi.org/10.24014/jp. v11i2.1398
Tinto, V. (2006). Research and practice of student retention: what next? Journal of College Student Retention Research Theory and Practice, 8(1), 1-19. https://doi.org/10.2190/C0C4-EFT9EG7W-PWP4

UIN Alauddin Makassar. (2013). Handbook of UIN Alauddin Makassar Students. Makassar: CV. Berkah Utami.

Utomo, D. W. (2009). Hambatan, Motivasi, dan Strategi Pemecahan Masalah pada Mahasiswa Psikologi Universitas Sanata Dharma Yang Sedang Menyelesaikan Skripsi (Skripsi). Yogyakarta: Universitas Sanata Dharma Yogyakarta.

Von Simson, K. (2015). Explaining upper secondary school dropout: New evidence on the role of local labor markets. Empirical Economics, 48, 1419-1444. https://doi.org/10.1007/s00181-0140829-3

Willging, P. A., \& Johnson, S. D. (2004). Factors that influence students' decision to dropout of online courses. Journal of Asynchronous Learning Networks, 8(4), 105-118. https://doi.org/dx.doi.org/10.24059/olj .v13i3.1659

Yuliani. (2013). Motivasi Mahasiswa dalam Menyelesaikan Studi di Jurusan Kesejahteraan Keluarga Fakultas Teknik Universitas Negeri Padang (Skripsi). Padang: Universitas Negeri Padang.

Zhang, Q., Bonafini, F. C., Lockee, B. B., Jablokow, K. W., \& Hu, X. (2019). Exploring Demographics and Students' Motivation as Predictors of Completion of a Massive Open Online Course. International Review of Research in Open and Distributed Learning, 20(2), 140-161. https://doi.org/10.19173/irrodl.v20i2.3 
210| Psikis : Jurnal Psikologi Islami Vol. 7 No. 2 December 2021

730

Zohar, D., \& Marshall, I. (2000). SQ: Spiritual Intelligence The Ultimate Intelligence. London: Vloomsbury Publishing. 